\title{
POLITIKK
}

SKANDINAVISK TIDSSKRIFT

FOR INTERNASJONALE STUDIER

Årgang 78, Nummer 4, side 445-455, 2020, ISSN 1891-1757, www.tidsskriftet-ip.no, Publisert desember 2020

FOKUS: NORGE, NORDOMRÅDENE OG UTENRIKSPOLITIKK

\section{Introduksjon til fokusnummer: Norge, nordområdene og utenrikspolitikk}

\author{
Andreas Østhagen \\ Fridtjof Nansens institutt og Nordområdesenteret ved Nord universitet, Norge
}

\begin{abstract}
Sammendrag
Når regjeringen legger fram en ny stortingsmelding om nordområdene høsten 2020, er det nesten et tiår siden forrige melding ble presentert. Veldig mye har endret seg siden da, ikke minst i form av Kinas fremvekst, økt spenning mellom NATO og Russland, og en reaksjonær amerikansk president. Nordområdene og hele det sirkumpolare Arktis har blitt en arena for symbolpolitikk og militær øvelsesaktivitet, samtidig som de arktiske landene fortsetter å samarbeide om en rekke saker. Midt i dette står Norge. Denne introduksjonsartikkelen til fokusnummeret om Norge, nordområdene og utenrikspolitikk trekker de store linjene i utviklingen de seneste årene med hensyn på Norges posisjon og rolle. Den introduserer også de andre bidragene og peker på noen av de mest aktuelle funnene som vi bli diskutert.
\end{abstract}

Nøkkelord: nordområdene · Arktis · Russland $\cdot$ Kina $\cdot$ USA $\cdot$ utenrikspolitikk

Et tiår er mye i en del av verden som endrer seg raskt. Nordområdene ser annerledes ut nå enn sist gang en regjering la frem en nordområdemelding. Smeltingen av havisen har akselerert. Fiskebestander som den norsk-arktiske torsken trekker stadig lenger nord. Kina har lagt frem en Arktis-strategi. Gigaprosjektet Yamal LNG i Russland som i 2011 eksisterte kun på papiret - har gitt økt skipsfart langs den nordlige sjørute. Andre håpefulle økonomiske prosjekter, som Shtockman, har blitt skrinlagt.

\footnotetext{
^Kontaktinformasjon: Andreas Østhagen, e-post: ao@fni.no

(C)2020 Andreas Østhagen. This is an Open Access article distributed under the terms of the Creative Commons Attribution 4.0 International License (http://creativecommons.org/licenses/by/4.0/), allowing third parties to copy and redistribute the material in any medium or format and to remix, transform, and build upon the material for any purpose, even commercially, provided the original work is properly cited and states its license.

Citation: Østhagen, A. (2020). Introduksjon til fokusnummer: Norge, nordområdene og utenrikspolitikk. Internasjonal Politikk, 78(4), 445-455. http://dx.doi.org/10.23865/intpol.v78.2403
} 
Da nordområdesatsingen så dagens lys for 15 år siden, var den et optimistisk løfte om økt oppmerksomhet nordover, nye økonomiske muligheter og styrking av dialogen med Russland (Medby, 2014). I starten så det da også riktig lovende ut: I 2010, etter at delelinjeavtalen i Barentshavet var i boks, erklærte Russlands daværende president Medvedev en «ny æra» i forholdet mellom Norge og Russland (Aftenposten, 2010). Et grenseboerbevis, slik at innbyggerne i Øst-Finnmark kan reise visumfritt over grensen til Russland, kom på plass i 2012. Arktisk råd ble hyllet som samarbeidsorganet som skulle sikre freden i nord (Rottem, 2010). Norge fikk lagt sekretariatet til Tromsø i 2011, og land som India, Japan, Kina og Singapore kom inn som observatører i rådet i 2013.

Men så, i 2014, snudde stemningen. Først og fremst var det den russiske annekteringen av Krim som bidro til en kraftig forverring av samarbeidsklimaet i nord. Oljeprisfall førte også til at mange av de økonomiske interessene knyttet til nordområdesatsingen forsvant. De som hadde forventet (eller håpet på) et Klondyke ${ }^{1} \mathrm{i}$ nord, ble skuffet, og entusiasmen rundt hele nordområdesatsingen begynte å kjølne. Den gikk fra å være en «satsing» til å bli et «ansvar», ${ }^{2}$ og regional- og næringspolitiske prioriteringer har ofte vært mer fremtredende enn de utenrikspolitiske.

For Nord-Norge, som utgjør en tredel av Norges landareal, 10 prosent av befolkningen og hele 80 prosent av havområdene, ${ }^{3}$ var satsingen på håndfaste infrastruktur- og næringsprosjekter utvilsomt både velkommen og etterlengtet. Utenrikspolitikk og innenrikspolitikk er heller ikke motsetninger - noe nordområdesatsingen er det ypperste eksemplet på. Et levende lokalsamfunn på Svalbard, et aktivt næringsliv i Kirkenes eller en styrking av den samiske retten til selvbestemmelse bidrar til å styrke Norges posisjon i nordområdene.

Samtidig er ikke alt som er regionalpolitikk, utenrikspolitikk, og vice versa. Og det er mange munner som skal mettes når en ny nordområdemelding lanseres. Utenriksdepartementet har derfor stått i en vanskelig spagat når det skal forfatte meldingen. Denne gangen har jobben trolig vært ekstra vanskelig, også med hensyn på utenrikspolitikk.

I 2020 er vi nemlig på vei inn i en tredje fase av norsk nordområdepolitikk - en fase preget av stormaktrivalisering og hard retorikk utenfor Norges landegrenser. Norge er ikke like tydelig i førersetet for utviklingen i det sirkumpolare nord som vi var for 15 år siden. Amerikanske, russiske og etter hvert også kinesiske og europeiske statsledere er i ferd med å sette agendaen. Høsten 2019 omtalte Frankrikes forsvarsminister Arktis som «det nye Midtøsten» (French Ministry of Armed Forces, 2019). Og selv om uttalelsen var i overkant spekulativ og dramatisk - forskere har stort sett forkastet tanken om en gryende ressurskrig i nord (Byers, 2017; Hoel, 2014; Tamnes

\footnotetext{
${ }^{1}$ Begrepet «Klondyke» refererer i og for seg til ressursutvinning i nettopp Arktis, nemlig gullrushet til stedet Klondike i det nordlige Canada i 1896.

${ }^{2}$ Utenriksdepartementets beskrivelse på nettsiden: https://www.regjeringen.no/no/tema/nordomradene/id1154/

${ }^{3}$ Dette inkluderer havområdene rundt Svalbard og Jan Mayen.
} 
\& Offerdal, 2014; Wilson Rowe, 2020) - eksemplifiserer den hvordan synet på nordområdene har endret seg. Flere og flere land retter nå blikket mot nord og ser ut til å ville bruke Arktis som en arena for utenrikspolitisk innflytelse og symbolpolitikk.

Årsakene til den voksende interessen er flere, men koker ned til to sentrale aktører: Russland og Kina. Russland arbeider for å gjenreise sin militære og politiske makt, og Arktis er et av de geografiske områdene der dette giøres relativt uhindret. Landet har allerede en dominerende posisjon i området, med Nordflåten - som innbefatter Russlands strategiske atomubåter - basert på Kolahalvøya (Konyshev \& Sergunin, 2014; Zysk, 2013). I Arktis er Russland en stormakt, gitt både dets geografiske posisjon og det relativt høye befolkningstallet, i sammenheng med økonomiske og militære interesser (Claes \& Moe, 2018).

Kina er på sin side mer av en nykommer, og da landet i 2018 omtalte seg selv som en «nær-arktisk stat», var det nok flere i de arktiske landenes utenriksministerier som hevet et og annet øyenbryn (Guo \& Wilson, 2020). Formuleringen signaliserte tydelig at Beijing ønsket en mer aktiv rolle i nord (Koivurova \& Kopra, 2020). Kanskje er det likevel ikke så overraskende. Kina har økt sin tilstedeværelse en rekke steder de siste årene, som del av en global maktutvidelse med både myke og harde vendinger (f.eks. Lunde, Yang \& Stensdal, 2016).

Russlands vedvarende satsing og Kinas inntog i nord trigget USA og president Donald Trump til å ta en mer fremoverlent rolle i Arktis. USAs utenriksminister Pompeos advarsel i 2019 om at Kina risikerer å skape et "nytt Sør-Kina-hav» i nord (US Department of State, 2019), illustrerer på mange måter hvordan Trump-administrasjon så på Arktis. Det var nok en arena der USA kan utfordre, eller stagge, fremveksten av Kina (f.eks. Tunsjø, 2018). I et slikt perspektiv er heller ikke Trumps uttalelser i 2019 om å «kjøpe» Grønland helt tilfeldige. De blir ledd i en sikkerhetspolitisk tilnærming der USA først og fremst snakker til Kina (og dernest verden) (Bye, 2020; Østhagen, 2019). Spørsmålet er hvilken tilnærming til Arktis en Biden-administrasjon vil ta fra 2021.

Av de ulike delene av Arktis er det i den europeiske delen - Norges nord- og nærområder - at utfordringene er størst. Her øker militær tilstedeværelse og provokativ øvelsesaktivitet (Bruland \& Bendixen, 2019; Norum, 2018). Aftenposten beskriver denne utviklingen som en gryende «maktkamp på Norges dørstokk» (I. Moe, 2020).

Mye av Norges utenrikspolitikk i nord defineres av Russland. Etter 2014 har derimot økonomiske samarbeidsprosjekter med Norge blitt satt på vent eller skrinlagt, samtidig som militære øvelser og provokative uttalelser fra Kreml, rettet mot blant annet Norge, har økt i omfang. NATO-øvelsen Trident Juncture i 2018 - den største i Norge siden den kalde krigen - var et svar på Russlands økte militære aktivitet i Nord-Europa og nordområdene. Amerikanske tropper øver mer i Norge enn på flere tiår. I mai 2020 gjennomførte den amerikanske og den britiske marinen «maritime security operations» i Barentshavet, uten norsk deltakelse (US Navy, 2020).

Russland agerer og reagerer på Norges og NATOs handlinger. I forbindelse med Svalbardtraktatens hundreårsjubileum i februar 2020 blåste Russland liv i den 
ulmende konflikten om hvem som har rett på hva i øygruppens farvann (Ministry of Foreign Affairs of the Russian Federation, 2020). Samtidig ønsker Norge et godt og konstruktivt forhold til naboen i øst. Alternativet er mye verre.

Den sikkerhetspolitiske situasjonen i nordområdene og Arktis ${ }^{4}$ er altså en ganske annen enn den var i 2011, da forrige stortingsmelding om nordområdene ble lagt frem (Utenriksdepartementet, 2011). Der Norge for et tiår siden ønsket å bygge broer i den arktiske regionen og utvikle nye former for samarbeid, står vi i dag i en langt mer defensiv posisjon. Regjeringen forsøker å bevare de positive dynamikkene som ennå finnes i regionen, men i det store og hele er tonen langt mindre håpefull, og utenriksminister Eriksen Søreide må balansere hårfint mellom et provokativt naboland som tester Norges (og NATOs) grenser, og en president i Det hvite hus som ser verden i sort hvitt.

Utviklingen det siste tiåret fordrer at vi ser nærmere på nettopp de internasjonale og utenrikspolitiske dimensjonene Norge må forholde seg til i våre nordog nærområder. Selv om det er begrenset fare for en "kamp om ressurser» i nord (Holtsmark, 2020), har nordområdene blitt mer sentrale for den sikkerhetspolitiske interaksjonen mellom NATO og Russland og i et strategisk (og til tider symbolsk) spill mellom Kina og USA. Her er det viktig å skille mellom is og bart.

I dette fokusnummeret retter vi derfor søkelyset på hva som skjer i nordområdene. I sammenheng med regjeringens kommende nordområdemelding høsten 2020 spør vi: Hva har endret seg? Hva er de utenrikspolitiske dynamikkene som nå preger regionen? Og ikke minst: Hvor står Norge i dette bildet?

Selv om mye av dette ikke er direkte berørt i stortingsmeldingen - den har tross alt et annet formål enn dette fokusnummeret og skal favne bredt - er mange av de komponentene vi diskuterer her, også fremtredende i meldingen. Mye kan også leses mellom linjene, eller ved å sammenligne med tidligere stortingsmeldinger om samme tema. Formålet vårt er å løfte frem og diskutere helt sentrale spørsmål for utformingen av norsk utenriks- og sikkerhetspolitikk i nord.

Fremfor å inndele bidrag rettet mot spesifikke saksfelt eller enkeltaktører diskuterer vi de politiske dynamikkene på et litt mer generelt nivå. Den norske forskningen på sikkerhets- og utenrikspolitikk i Arktis/nordområdene har vokst de siste to tiårene og er på mange områder verdensledende, på tross av et relativt lavt antall forskere. ${ }^{5} \mathrm{Vi}$ kunne lett ha doblet antall bidrag om plassbegrensninger ikke eksisterte.

\footnotetext{
${ }^{4}$ Merk at det gjøres et skille mellom «nordområdene» og «Arktis» her. Nordområdene (ofte betegnet "High North» på engelsk) har i mange sammenhenger blitt brukt for å betegne de umiddelbare områdene i nord som er en del av - eller tilstøtende - Norge. Dette innbefatter Barentshavet inkludert Svalbard, men da ikke hele det polare området. Arktis, derimot, brukes som betegnelse for hele den sirkumpolare regionen, altså hele området nord for Polarsirkelen. Det skal samtidig bemerkes at et slikt skille ikke nødvendigvis er entydig akseptert, da man fra norsk offentlig hold ofte bruker nordområdene og Arktis om hverandre. Se Skagestad (2014) for en lengre diskusjon om begrepsbruk og nordområdene.

${ }^{5}$ Bidragene fra norske forskningsmiljøer med vekt på sikkerhetspolitikk og/eller internasjonal politikk i nordområdene er mangfoldige og favner bredt. Et lite utvalg av disse nevnes her:
} 
Likevel favner dette fokusnummeret både bredt og dypt - fra sikkerhetspolitikk og Svalbard-strid til Kina og identitetspolitikk i nord. Forskere fra ulike akademiske institusjoner og fra ulike deler av landet bidrar. Innfallsvinklene er flere. Målet er å stimulere til en bredere utenrikspolitisk debatt om hva Norge kan, og eventuelt burde, satse på i nord. Vi gir ikke alle svarene, men ønsker å reise en debatt om det som tross alt er Norges "viktigste strategiske ansvarsområde».

Fokusnummeret starter med et bidrag fra Norges utenriksminister, Ine Eriksen Søreide, som skisserer den sittende regjeringens tanker rundt nordområdene, og hva som er nytt i stortingsmeldingen som legges frem til i 2020. Deretter reflekterer partileder og tidligere utenriksminister Jonas Gahr Støre rundt starten på nordområdesatsingen da den «rødgrønne» regjeringen overtok i 2005, samt hvordan Arbeiderpartiet ser veien videre for internasjonal politikk i nordområdene.

De tre første fagbidragene beskriver, kontekstualiserer og diskuterer den utenriksog sikkerhetspolitiske situasjonen i nordområdene og Arktis. Det starter med at Andreas Østhagen og Svein Vigeland Rottem presenterer de stormaktpolitiske utviklingstrekkene anno 2020. Forfatterne deler inn i tre nivåer - det internasjonale, det regionale og det nasjonale - hvor ulike dynamikker langs en konflikt-samarbeid-akse gjør seg gjeldende. Dette er med på å nyansere oppfatningen om Arktis som en arena for konkurranse og rivalisering.

Ingeborg Bjur, Karen-Anna Eggen og Paal Sigurd Hilde tar opp denne tråden og snevrer inn søkelyset ved å se på sammenhengen mellom sikkerhetspolitikk og

For et fokus på Norges generelle tilnærming til nordområdepolitikk og/eller sikkerhetspolitikk, se Bye, 2020; Flikke, 2011; Friis, 2019; Hønneland \& Rowe, 2010; L. C. Jensen, 2014, 2016a, 2016b; L. C. Jensen \& Rottem, 2011; Kristoffersen \& Young, 2010; Østhagen, Sharp \& Hilde, 2018; Pedersen, 2018; Skagestad, 2014; Tamnes, 2011; Wegge, 2011.

For et fokus på forholdet til Russland eller russisk Arktis-politikk, se Åtland, 2011; Åtland \& Ven Bruusgaard, 2009; Fjærtoft, Moe, Smirnova \& Cherepovitsyn, 2018; Hønneland, 1998, 2012, 2016; Leland, Hoel, Aalto, Blakkisrud \& Smith, 2008; A. Moe, Fjærtoft \& Øverland, 2011; Østhagen, 2016; Østreng \& Prydz, 2007; Rowe, 2015; Skripnikova \& Raspotnik, 2020; Wilson Rowe \& Blakkisrud, 2014; Zysk, 2011, 2013.

For et fokus på den generelle utviklingen i regionen med vekt på sikkerhetspolitikk, geopolitikk og/eller ressurser, se Åtland, 2008, 2014; Claes \& Moe, 2018; Gade \& Hilde, 2015; Holtsmark, 2009; Gjørv, Lanteigne \& Sam-Aggrey, 2020; Keskitalo, 2007; Lanteigne, 2016; Østhagen, 2020; Østreng, 1999; Rottem, 2010; Tamnes \& Holtsmark, 2014; Tamnes \& Offerdal, 2014; Wilson Rowe, 2020.

For et fokus på Kina og/eller asiatiske lands interesser i Arktis, se Bekkevold \& Offerdal, 2014; Bertelsen \& Gallucci, 2016; Lanteigne, 2015; Lunde, Yang \& Stensdal, 2016; Lundestad \& Tunsjø, 2014; A. Moe \& Stokke, 2019; Røseth, 2014; Stokke, 2014a; Wilson Rowe \& Lindgren, 2013.

For et eksplisitt fokus på Svalbard, se A.-K. Jørgensen \& Østhagen, 2020; J. H. Jørgensen, 2010; Østhagen \& Raspotnik, 2019; Pedersen, 2009, 2017; Pedersen \& Henriksen, 2009; Tiller \& Nyman, 2017; Ulfstein, 1995.

For vekt på styringsmekanismene i Arktis, Arktisk råd og/eller legale rammeverk, se Graczyk \& Rottem, 2020; Henriksen \& Ulfstein, 2011; Hoel, 2009, 2014; Ø. Jensen, 2011; Ø. Jensen \& Rottem, 2010; Prip, 2017; Rottem, 2017, 2020; Stokke, 2014b, 2017, 1990.

For et fokus på EUs rolle i Arktis og Norges interaksjoner med EU, se Offerdal, 2011; Østhagen, 2011; Østhagen \& Raspotnik, 2017; Raspotnik, 2018; Wegge, 2012. 
nordområdepolitikk i Norges nordområdesatsing. Denne innfallsvinkelen brukes så for å vurdere russisk syn på den samme satsingen, før forfatterne trekker frem et konkret eksempel på praktisk dialog med Russland - INCSEA-avtalen. Samarbeidsmekanismer som denne er med på å bygge tillit og opprettholde dialog, på tross av en relativt spent sikkerhetspolitisk situasjon i nord.

Til slutt i denne delen av fokusnummeret ser Torbjørn Pedersen og Odd Gunnar Skagestad på hvordan nordområdebegrepet og den tilknyttede politikken har endret seg over to tiår. De spør i hvilken grad nordområdepolitikken ivaretar aktuelle sikkerhetspolitiske utfordringer i de samme områdene? Deretter argumenteres det for at selv om politikkutforming må håndtere kompleksitet, kan ikke nordområdepolitikken være en politikk for alt - den må spisses og tydeliggjøres med hensyn på nettopp sikkerhetspolitiske utfordringer.

I den andre delen av fokusnummeret rettes søkelyset mot spesifikke aspekter ved internasjonal politikk i nordområdene av relevans for Norge. Alf Håkon Hoel skisserer først hvordan fiskeriforvaltning og samarbeid spiller en helt sentral rolle som et utenrikspolitisk verktøy i nordlige farvann. Samarbeidet med andre land i Norskehavet, Barentshavet og Polhavet legger grunnlaget for den bærekraftige forvaltningen av det som historisk har vært, og i fremtiden vil være, den viktigste naturressursen $\mathrm{i}$ nord.

Arild Moe og Øystein Jensen følger opp med et tilsvarende søkelys på hav og havpolitikk, spesielt rettet mot Svalbard. Selv om Norges svalbardpolitikk håndteres av en egen stortingsmelding (Justis- og beredskapsdepartementet, 2016), er øygruppen som gir Norge direkte tilgang til Polhavet, utvilsomt også en sentral del av nordområdepolitikken. Svalbards noe spesielle forordninger samt disputten mellom Norge og noen tredjeland - herunder Russland - om havområdene rundt øygruppen fordrer at vi forstår Svalbards rolle i norsk utenrikspolitikk i nord.

Vi kommer heller ikke utenom Kina. Selv om fokusnummeret har valgt ikke å legge vekt på alle enkeltaktørene av relevans for norsk utenriks- og sikkerhetspolitikk i nord - da ville EU, Russland, USA og de nordiske landene være sentrale krever Kinas arktiske engasjement særskilt oppmerksomhet. For bare noen få år siden var Kinas interesser i nordområdene oppfattet på lik linje med andre ikke-arktiske stater. Men Kinas globale fremvekst, uttalte interesser i nord og ikke minst Trumpadministrasjonens valg om å konfrontere eller stagge Kina langs en rekke politikkområder - herunder også Arktis - gjør at Anders Edstrøm, Iselin Stensdal og Gørild Heggelund tar en ekstra titt på «den nye supermaktens» nordlige ambisjoner. Forfatterne starter med å beskrive hvordan kinesisk arktispolitikk utformes, før de undersøker Kinas uttalelser og handlinger i Arktis med spesiell vekt på Norge.

Avslutningsvis samler Beate Steinveg og Ingrid Medby trådene i en vurdering av hva nordområdepolitikken leder til i form av identitetsbygging og ideer om «nord». De beskriver hvordan bruken av narrativer fra Norges toppolitikere ikke bare handler om stortingsmeldinger, men også om hvordan nordområdenarrativet spiller en rolle som utenrikspolitisk posisjonering. Dette bygger opp under norske 
utenrikspolitiske interesser ved at internasjonalt samarbeid og havretten vektlegges, samtidig som Norge tar et tydelig (internasjonalt) standpunkt om at Arktis ikke skal "vernes», men heller forvaltes av folket som bor der. Som forfatterne konkluderer, «nordområdenarrativet har ennå ikke nådd sitt klimaks», selv om noe av euforien er borte.

Dette fokusnummeret og bidragene er satt sammen i forkant av regjeringens nordområdemelding. Det er derimot tvilsomt at den nye stortingsmeldingen vil sjokkere eller være et markant brudd med tidligere meldinger og strategidokumenter spesielt innen feltet utenriks- og sikkerhetspolitikk. Temaene som diskuteres her, vil være gjengangere i meldingen. Samtidig er formålet med de ulike bidragene å kontekstualisere situasjonen som en ny melding har blitt forfattet i og skal ta for seg. Områdene i nord har alltid vært viktige for Norge - og det er lite som tilsier at satsingen i nord ikke vil vedvare i det nye tiåret, selv om form og farge nok vil komme til å endre seg.

\section{Referanser}

Aftenposten. (2010, 15. september). Grenselinjeavtalen undertegnet. Aftenposten. https://www.aftenposten.no/ verden/i/Vqojr/grenselinjeavtalen-undertegnet

Bekkevold, J. I. \& Offerdal, K. (2014). Norway's High North policy and new Asian stakeholders. Strategic Analysis, 38(6), 825-840.

Bertelsen, R. G. \& Gallucci, V. (2016). The return of China, post-Cold War Russia, and the Arctic: Changes on land and at sea. Marine Policy, 72(oktober), 240-245.

Bruland, W. \& Bendixen, A. (2019, 29. mars). Amerikanske bombefly i øvelse fire steder nær Russlands grense. NRK. https://www.nrk.no/tromsogfinnmark/amerikanske-bombefly-i-ovelse-fire-steder-naer-russlandsgrense-1.14494969

Bye, H.-G. (2020). Leaving its Arctic reluctance behind: The re-emergence of U.S. security policy focus towards the European High North and its implications for Norway. The Polar fournal, 10(1).

Byers, M. (2017). Crises and international cooperation: An Arctic case study. International Relations, 31(4), 375-402.

Claes, D. H. \& Moe, A. (2018). Arctic offshore petroleum: Resources and political fundamentals. I S. V. Rottem, I. F. Soltvedt \& G. Hønneland (Red.), Arctic governance:Volume 2. Energy, living marine resources and shipping (s. 9-26). London, England: I.B. Tauris.

Fjærtoft, D., Moe, A., Smirnova, N. \& Cherepovitsyn, A. (2018). Unitization of petroleum fields in the Barents Sea: Towards a common understanding? Arctic Review on Law and Politics, 9, 72-96.

Flikke, G. (2011). Norway and the Arctic: Between multilateral governance and geopolitics. I J. Kraska (Red.), Arctic security in an age of climate change (s. 64-85). Cambridge, England: Cambridge University Press.

French Ministry of Armed Forces. (2019). France and the new strategic challenges in the Arctic. https://www. defense.gouv.fr/english/layout/set/print/content/download/565142/9742558/version/3/file/France + and $+\mathrm{t}$ he+New+Strategic+Challenges+in+the+Arctic+-+DGRIS_2019.pdf

Friis, K. (2019). Norway: NATO in the North? I N. Vanaga \& T. Rostoks (Red.), Deterring Russia in Europe: Defence strategies for neighbouring states (1. utg.). Abingdon, England: Routledge.

Gade, J. \& Hilde, P. S. (2015). Nordområdenes sikkerhetspolitiske betydning for NATO. I T. Heier \& A. Kjølberg (Red.), Norge og Russland: Sikkerhetspolitiske utfordringer $i$ nordområdene (s. 96-110). Oslo: Universitetsforlaget.

Gjørv, G. H., Lanteigne, M. \& Sam-Aggrey, H. (Red.). (2020). Routledge handbook of Arctic security. Abingdon, England Routledge.

Graczyk, P. \& Rottem, S.V. (2020). The Arctic Council: Soft actions, hard effects? I G. H. Gjørv, M. Lanteigne \& H. Sam-Aggrey (Red.), Routledge handbook of Arctic security (s. 221-233). Abingdon, England: Routledge.

Guo, L. \& Wilson, S. L. (2020, 29. mars). China, Russia, and Arctic geopolitics. The Diplomat. https:// thediplomat.com/2020/03/china-russia-and-arctic-geopolitics/ 


\section{Andreas Østhagen}

Henriksen, T. \& Ulfstein, G. (2011). Maritime delimitation in the Arctic: The Barents Sea Treaty. Ocean Development $\mathcal{E}$ International Law, 42(1-2), 1-21.

Hoel, A. H. (2009). Do we need a new legal regime for the Arctic Ocean? The International fournal of Marine and Coastal Law, 24(2), 443-456.

Hoel, A. H. (2014). The legal-political regime in the Arctic. I R. Tamnes \& K. Offerdal (Red.), Geopolitics and security in the Arctic (s. 49-72). New York: Routledge.

Holtsmark, S. G. (2009). Towards cooperation or confrontation? Security in the High North. NATO Defence College, (45), 1-12.

Holtsmark, S. G. (2020, 23. januar). Full forvirring om Arktis, Norge og Russland. Aftenposten. https:// www.aftenposten.no/meninger/debatt/i/RRBKoJ/full-forvirring-om-arktis-norge-og-russland-sven-gholtsmarkhttps://www.aftenposten.no/meninger/debatt/i/RRBKoJ/full-forvirring-om-arktis-norge-ogrussland-sven-g-holtsmark

Hønneland, G. (1998). Identity formation in the Barents Euro-Arctic Region. Cooperation and Conflict, 33(3), 277-297.

Hønneland, G. (2012). Norsk-russisk miljø- og ressursforvaltning i nordområdene. Nordlit, (29). http:// septentrio.uit.no/index.php/nordlit/article/viewFile/2303/2134

Hønneland, G. (2016). Russia and the Arctic: Environment, identity and foreign policy. London, England: I.B. Tauris.

Hønneland, G. \& Rowe, L. (2010). Nordområdene - hva nå? Trondheim: Tapir Akademisk Forlag.

Jensen, L. C. (2014). The times they are a-changin': Norsk sikkerhet og usikkerhet i nordområdene. Internasjonal Politikk, 72(1), 7-29.

Jensen, L. C. (2016a). From the High North to the Low South: Bipolar Norway's Antarctic strategy. Polar fournal, 6(2), 273-290.

Jensen, L. C. (2016b). International relations in the Arctic: Norway and the struggle for power in the New North. London, England: I.B. Tauris.

Jensen, L. C., Jensen, Ø. \& Rottem, S. V. (2011). Norwegian foreign policy in the High North: Energy, international law and security. Atlantisch Perspectief, 35(3), 1-7.

Jensen, Ø. (2011). The Barents Sea: Treaty between Norway and the Russian Federation concerning maritime delimitation and co-operation in the Barents Sea and the Arctic Ocean. International fournal of Marine and Coastal Law, 26(1), 151-168.

Jensen, Ø. \& Rottem, S.V. (2010). The politics of security and international law in Norway's arctic waters. Polar Record, 46(236), 75-83.

Justis- og beredskapsdepartementet. (2016). Svalbard (Meld. St. 32 (2015-2016)). https://www.regjeringen. no/no/dokumenter/meld.-st.-32-20152016/id2499962/

Jørgensen, A.-K. \& Østhagen, A. (2020). Norges vern av suverene rettigheter rundt Svalbard: Russiske persepsjoner og reaksjoner. Internasjonal Politikk, 78(2), 167-192.

Jørgensen, J. H. (2010). Russisk svalbardspolitikk. Trondheim: Tapir Akademiske Forlag.

Keskitalo, C. (2007). International region-building: Development of the Arctic as an international region. Cooperation and Conflict, 42(2), 187-205.

Koivurova, T. \& Kopra, S. (Red.). (2020). Chinese policy and presence in the Arctic. Leiden: Brill Nijhoff.

Konyshev, V. \& Sergunin, A. (2014). Is Russia a revisionist military power in the Arctic? Defense and Security Analysis, 30(4), 323-335.

Kristoffersen, B. \&Young, S. (2010). Geographies of security and statehood in Norway's "Battle of the North». Geoforum, 41(4), 577-584.

Lanteigne, M. (2015). The role of China in emerging Arctic security discourses. Security and Peace, 33(3), 150-155.

Lanteigne, M. (2016). Ties that bind:The emerging regional security complex in the Arctic. NUPI Policy Brief, $4,1-4$.

Leland, S. R., Hoel, A. H., Aalto, P., Blakkisrud, H. \& Smith, H. (2008). Learning by doing: The Barents cooperation and development of regional collaboration in the north. I P. Aalto, A. Aasland, M. Anker, H. Blakkisrud, B. Brunstad, I. Busygina, ... I. Overland (Red.), The new northern dimension of the European neighbourhood (s. 36-54). Brussel: Centre for European Policy Studies.

Lunde, L., Yang, J. \& Stensdal, I. (Red.). (2016). Asian countries and the Arctic future. Singapore: World Scientific.

Lundestad, I. \& Tunsjø, Ø. (2014). The United States and China in the Arctic. Polar Record, FirstView (259), $1-12$. 
Medby, I. A. (2014). Arctic state, Arctic nation? Arctic national identity among the post-Cold War generation in Norway. Polar Geography, 37(3), 252-269.

Ministry of Foreign Affairs of the Russian Federation. (2020). Press release on Foreign Minister Sergey Lavrov's message to Norwegian Foreign Minister Ine Eriksen Soreide on the occasion of the 100th anniversary of the Spitsbergen Treaty. https://norway.mid.ru/en/embassy/press-centre/news/press_release_on_foreign_ minister_sergey_lavrov_s_message_to_norwegian_foreign_minister_ine_eriksen_/

Moe, A., Fjærtoft, D. \& Øverland, I. (2011). Space and timing: Why was the Barents Sea delimitation dispute resolved in 2010? Polar Geography, 34(3), 145-162.

Moe, A. \& Stokke, O. S. (2019). Asian countries and arctic shipping: Policies, interests and footprints on governance. Arctic Review on Law and Politics, 10, 24-52.

Moe, I. (2020, 22. februar). Arktis smelter. Slik bidrar det til maktkamp på Norges dørstokk. Aftenposten. https://www.aftenposten.no/verden/i/awBvA5/arktis-smelter-slik-bidrar-det-til-maktkamp-paa-norgesdoerstokk

Norum, H. (2018, 5. mars). - Russland simulerte angrep på Vardø-radar. NRK. https://www.nrk.no/norge/_russland-simulerte-angrep-pa-vardo-radar-1.13946450

Offerdal, K. (2011). The EU in the Arctic: In pursuit of legitimacy and influence. International fournal, 66(4), $861-877$.

Pedersen, T. (2009). Endringer i internasjonal Svalbard-politikk. Internasjonal Politikk, 67(1), 31-44.

Pedersen, T. (2017). The politics of presence: The Longyearbyen dilemma. Arctic Review on Law and Politics, $8,95-108$.

Pedersen, T. (2018). Når nordområdene lever sitt eget liv. Internasjonal Politikk, 76(3), 140-158.

Pedersen, T. \& Henriksen, T. (2009). Svalbard's maritime zones: The end of legal uncertainty? The International Fournal of Marine and Coastal Law, 24(1), 141-161.

Prip, C. (2017). The Arctic Council and biodiversity. I S. V. Rottem \& I. F. Soltvedt (Red.), Arctic governance: Law and politics. Volume 1. (s. 205-230). London, England: I.B. Tauris.

Raspotnik, A. (2018). The European Union and the geopolitics of the Arctic. Cheltenham, England: Edward Elgar.

Rottem, S. V. (2010). Klima og sikkerhet i Arktis. Internasjonal Politikk, 68(2), 183-204.

Rottem, S. V. (2017). The Arctic Council: Challenges and recommendations. I S. V. Rottem \& I. F. Soltvedt (Red.), Arctic governance: Law and politics. Volume 1 (s. 231-251). London, England: I.B. Tauris.

Rottem, S. V. (2020). The Arctic Council: Between environmental protection and geopolitics. London, England: Palgrave Macmillan.

Rowe, L. (2015). Fra unntakstilstand til en ny normal. I S. G. Holtsmark (Red.), Naboer i frykt og forventning: Norge og Russland 1917-2014 (s. 628-632). Oslo: Pax Forlag.

Røseth, T. (2014). Russia's China policy in the Arctic. Strategic Analysis, 38(6), 841-859.

Skagestad, O. G. (2010). The "High North»: An elastic concept in Norwegian Arctic Policy (FNI rapport 10/2010). Lysaker: Fridtjof Nansens Institutt. https://www.fni.no/publications/the-high-north-an-elastic-conceptin-norwegian-arctic-policy-article821-290.html

Skripnikova, N. \& Raspotnik, A. (2020). Has Russia heard about the European Union's Arcticness? The EU's Arctic steps as seen from Russia. Polar Record, 56(1).

Stokke, O. S. (1990). The northern environment: Is cooperation coming? Annals of the American Academy of Political and Social Science, 512(1), 58-68.

Stokke, O. S. (2014a). Asian states and Arctic governance. Strategic Analysis, 38(6), 770-783.

Stokke, O. S. (2014b). International environmental governance and Arctic security. I R. Tamnes \& K. Offerdal (Red.), Geopolitics and security in the Arctic (s. 121-146). London, England: Routledge.

Stokke, O. S. (2017). Geopolitics, governance, and Arctic fisheries politics. I E. Conde \& S. I. Sánchez (Red.), Global challenges in the Arctic region: Sovereignty, environment and geopolitical balance (s. 170-195). London, England: Routledge.

Tamnes, R. (2011). Arctic security and Norway. I J. Kraska (Red.), Arctic security in an age of climate change (s. 47-64). Cambridge, England: Cambridge University Press.

Tamnes, R. \& Holtsmark, S. G. (2014). The geopolitics of the Arctic in historical perspective. I R. Tamnes \& K. Offerdal (Red.), Geopolitics and security in the Arctic: Regional dynamics in a global world. London, England: Routledge.

Tamnes, R. \& Offerdal, K. (2014). Conclusion. I R. Tamnes \& K. Offerdal (Red.), Geopolitics and security in the Arctic: Regional dynamics in a global world (s. 166-177). London, England: Routledge.

Tiller, R. \& Nyman, E. (2017). The clear and present danger to the Norwegian sovereignty of the Svalbard Fisheries Protection Zone: Enter the snow crab. Ocean and Coastal Management, 137, 24-33. 


\section{Andreas Østhagen}

Tunsjø, Ø. (2018). The return of bipolarity in world politics: China, the United States, and geostructural realism. New York: Columbia University Press.

Ulfstein, G. (1995). The Svalbard Treaty: From terra nullius to Norwegian sovereignty. Oslo: Aschehoug.

US Department of State. (2019). Looking north: Sharpening America's Arctic focus. https://www.state.gov/ looking-north-sharpening-americas-arctic-focus/

US Navy. (2020). U.S., U.K. ships operate in the Barents Sea. https://www.c6f.navy.mil/Press-Room/News/ Article/2174342/us-uk-ships-operate-in-the-barents-sea/

Utenriksdepartementet. (2011). Nordområdene:Visjon og virkemidler (Meld. St. 7 (2011-2012)). https://www. regjeringen.no/no/dokumenter/meld-st-7-20112012/id663433/

Wegge, N. (2011). Small state, maritime great power? Norway's strategies for influencing the maritime policy of the European Union. Marine Policy, 35(3), 335-342.

Wegge, N. (2012). The EU and the Arctic : European foreign policy in the making. Arctic Review on Law and Politics, 3(1), 6-29.

Wilson Rowe, E. (2020). Analyzing frenemies: An Arctic repertoire of cooperation and rivalry. Political Geography, 76.

Wilson Rowe, E. \& Blakkisrud, H. (2014). A new kind of Arctic power? Russia's policy discourses and diplomatic practices in the circumpolar North. Geopolitics, 19(1), 66-85.

Wilson Rowe, E. \& Lindgren, W.Y. (2013). Coming into the cold: Asia's Arctic interests. Polar Geography, 36(4).

Zysk, K. (2011). Military aspects of Russia's Arctic policy: Hard power and natural resources. I J. Kraska (Red.), Arctic security in an age of climate change (s. 85-106). Cambridge, England: Cambridge University Press.

Zysk, K. (2013). Russia's Arctic strategy: Ambitions and restraints. I B. S. Zellen (Red.), The fast-changing Arctic: Rethinking Arctic security for a warmer world (s. 281-296). Calgary, Alberta: Calgary University Press.

Østhagen, A. (2011). Utenrikspolitisk entreprenørskap: EU og utviklingen av en Arktis-politikk. Internasjonal Politikk, 69(1), 7-35.

Østhagen, A. (2016). High North, low politics. Maritime cooperation with Russia in the Arctic. Arctic Review on Law and Politics, 7(1), 83-100.

Østhagen, A. (2019, 8. desember). Fra spøk til alvor - vi må snakke om nordområdene. VG. https://www.vg.no/ nyheter/meninger/i/Jow9z4/fra-spoek-til-alvor-vi-maa-snakke-om-nordomraadene

Østhagen, A. (2020). Coast guards and ocean politics in the Arctic. London, England: Palgave Macmillan.

Østhagen, A. \& Raspotnik, A. (2017). Partners or rivals? Norway and the European Union in the High North. I N. Liu, E. A. Kirk \& T. Henriksen (Red.), The European Union and the Arctic (s. 97-119). Leiden: Brill Nijhoff.

Østhagen, A. \& Raspotnik, A. (2019). Why is the European Union challenging Norway over snow crab? Svalbard, special interests, and Arctic governance. Ocean Development E International Law, 50(2-3), 190-208.

Østhagen, A., Sharp, G. L. \& Hilde, P. S. (2018). At opposite poles: Canada's and Norway's approaches to security in the Arctic. Polar fournal, 8(1), 163-181.

Østreng, W. (1999). Strategic, legal and political implications of international shipping on the NSR. I C. L. Ragner (Red.), The 21st century - turning point for the Northern sea route? (s. 71-87). Basel, Sveits: Springer.

Østreng, W. \& Prydz, Y. (2007). Delelinjen i Barentshavet: Planlagt samarbeid versus uforutsett konflikt? (The Barents Sea boundary: Planned cooperation versus conflict?). Stortingets utredningsseksjon. https://www. stortinget.no/Global/pdf/Utredning/Perspektiv07_04.pdf

Åtland, K. (2008). Mikhail Gorbachev, the Murmansk initiative, and the desecuritization of interstate relations in the Arctic. Cooperation and Conflict, 43(3), 289-311.

Åtland, K. (2011). Russia's armed forces and the Arctic: All quiet on the northern front? Contemporary Security Policy, 32(2), 267-285.

Åtland, K. (2014). Interstate relations in the Arctic: An emerging security dilemma? Comparative Strategy, 33(2), 145-166.

Åtland, K. \& Ven Bruusgaard, K. (2009). When security speech acts misfire: Russia and the Elektron incident. Security Dialogue, 40(3), 333-353. 


\begin{abstract}
English
Introduction to Focus Issue: Norway, the High North and Foreign Policy When the Norwegian government presents a new report to the parliament on its High North policy in the autumn of 2020, almost a decade has passed since the previous report was presented. A lot has changed since then, not least in the form of China's emergence, increased tensions between NATO and Russia, and a reactionary US president. The High North and the entire circumpolar Arctic have become an arena for symbol politics and military exercise activity, while the Arctic countries continue to co-operate on a number of issues. In the middle of this is Norway. This introductory article to the focus issue on Norway, the High North and foreign policy examines the broad lines of developments in recent years with regard to Norway's position and role in the north. It also introduces the other contributions and points to some of the most relevant findings that are being discussed.
\end{abstract}

Keywords: High North · Arctic · Russia • China • USA · foreign policy 